Article

\title{
A Decision-Making Model for Adopting a Cloud Computing System
}

\author{
Seok-Keun Yoo and Bo-Young Kim * \\ Seoul Business School, Seoul School of Sciences and Technologies (aSSIST), Seoul 03767, Korea; \\ psskyoo@gmail.com \\ * Correspondence: bykim2@assist.ac.kr; Tel.: +82-10-4046-2428
}

Received: 25 July 2018; Accepted: 16 August 2018; Published: 20 August 2018

\begin{abstract}
The use of big data, artificial intelligence, and new information and communication technologies has led to sustainable developments and improved business competitiveness. Until recently cloud services were classified as having special system requirements for a business organization, and was represented by different cloud computing architecture layers like infrastructure, platform, or software as a service. However, as the environment of IT services undergoes successive changes, companies have been required to reconsider their business models and consider adopting a cloud computing system, which can bring on business achievements and development. Regarding a decision-making model for adopting a cloud computing system, this paper analyzes critical variables in a hierarchical structure of decision areas: technology, organization, and environment, as well as seven factors and 23 attributes based on underlying decision factors of cloud computing adoption by AHP (Analytic Hierarchy Process) and Delphi analysis. Furthermore, this research explores a comparative analysis between demanders and providers of cloud computing adoption. Resultantly, this study suggests several important factors for adopting a cloud computing system: top management support, competitive pressure, and compatibility. From the demander side, the high priority factor was compatibility and competitive pressure; in contrast, related advantage and top management support were regarded as priority factors for providers to service their cloud computing systems.
\end{abstract}

Keywords: cloud computing; system adoption; decision-making; digital transformation; big data; analytic hierarchy process

\section{Introduction}

It is a patent fact that many firms are in the process of digital transformation as they innovate traditional operations and services with digital transformation initiatives and technologies not only for their survival but for the profitable growth of business in the 4th industrial revolution (i.e., artificial intelligence (AI), autonomous vehicles, 3D printing, robots and drones, internet of things (IoT), big data analytics and cloud, and social media solutions) [1]. Cloud computing services have particularly continued to grow since it was announced in 2006. In the early days, infrastructure as a service (IaaS), which provided physical computing power such as servers, storage, and networks, was the basic service. But platform as a service (PaaS), which provides developers' a programming environment, has developed as a significant portion of cloud service. And software as a service (SaaS) has accounted for a considerable part of cloud services. Moreover, hybrid IT has been regarded as a part of the consideration of an IT infrastructure model. According to IDC (Internet Data Center) in South Korea [2], the rate of IT spending has been growing at a rate of 4.5 times since 2009, and it is positively anticipated to end up growing at a rate of better than 6 times more until 2020, boosting total spending on public cloud computing from $\$ 67$ billion in 2015 to $\$ 162$ billion in 2020. 
In the Korean cloud computing market, communication service providers such as Korea Telecommunication (KT) and SK Telecommunication (SKT) started cloud computing services for firms with services targeting existing individual customers since 2011. Moreover, the South Korean government launched G-Cloud [3,4], a cloud computing service for the government's public institutions in 2012. Therefore, the South Korean government enforced the Cloud Development Act in $2015[5,6]$ to boost the economy, pushing for changes in policies to take off as a leading cloud computing country by 2021. Global cloud service providers have set up data centers in South Korea and have buckled down on cloud computing services since 2015. In these environmental changes, firms have encountered an incremental understanding of the importance of cloud system adoption, and that using cloud computing is considered a common requirement factor for any initiative of digital transformation. According to International Data Group (IDG) [7] research results, the cloud has been expanding its base with various advantages such as agility, flexibility, and efficiency, and that over the last few years, four out of ten South Korean companies are using cloud computing, and $53.1 \%$ of conglomerates in Korea have already adopted cloud computing.

Considering this research, its purposes is to suggest a hierarchical decision structure model with the decision areas, factors, and attributes based on the underlying decision factors of cloud computing adoption. The model will support the decision prioritization for cloud computing service adoption and system management. Regarding prior research, the challenges and risk factors of cloud computing adoption were initially looked at its application to specific industries or countries.

However, modern structures of businesses have undergone rapid transformations affected by disruption models with new technologies. Also, the evolution of open-source technology, graphics processing unit (GPU) computing, and artificial intelligence (AI) is causing a huge difference in the cloud computing area. That is, businesses have to make a suitable decision on cloud computing adoption in order to reflect technological, organizational, and environmental changes, and that it is indispensable for them to consider highly organized and holistic influencing factors.

This study reviews the literature on cloud computing adoption and related research, and contributes to an understanding of the order of priority for area, factors, and attributes in a decision-making model, and attempts to grasp the difference between demander and provider priorities for cloud computing adoption. Finally, the suggested model and research results are helpful for an organization to make the right decision regarding cloud computing adoption in order to improve its digital transactions.

\section{Literature Review}

\subsection{Cloud Computing Services in the IT Industry}

Since 2000, social media and platform, big data analytics, artificial intelligence, and cloud computing use is increasingly rapidly [8]. These radical changes have led to successive innovations, which has been defined as a digital revolution [9]. This has been called the fourth industrial revolution, which has the "characteristic of a fusion of technologies that is blurring the lines between the physical, digital, and biological spheres." In this environment, service providers like Google and Amazon launched cloud computing service with the benefits of low cost and low maintenance on the market in 2006 [10]. Technologically, cloud computing involves various hardware, virtualization, distributed computing, and automation technologies based on the internet [11] and provides on-demand self-service including quick auto-provisioning and auto-scaling [12]. Cloud computing is referred to as a new term for a consumption model of computing [13] and is based on agreed service level agreements (SLAs) between demander and service providers [12]. The rapid emergence, its widespread nature, and the pervasive potential of cloud computing have resulted in a significant amount of concern and research in the IT industry [14].

Weiss [15] explained that the cloud computing concept was drawn on legacy architectures and technologies as various cloud shapes, software as a service, the data center, distributed computing, 
or a utility grid. However, cloud computing is a compelling idea which incorporates all sorts of computing models. Advanced academic studies of cloud computing, published between 2008 and 2012, explained conceptual and operational approaches [16]. For example, Armbrust et al. [13] defined that cloud computing is the application of services which are delivered over the internet, and where the hardware and system software for the services are located in data centers. Foster et al. [17] explained cloud computing as a distributed computing paradigm including abstraction, virtualization, dynamic scalability, and managed services. Mell and Grance [18] at the National Institute of Standards and Technology (NIST) also mentioned characteristics, service models, and deploy models of cloud computing and stated "cloud computing is a model for enabling ubiquitous, convenient, on-demand network access to a shared pool of configurable computing resources like networks, servers, storage, applications, and services that can be released with management effort or service interaction with provider. There are five essential characteristics; on-demand self-service, broad network access, resource pooling, rapid elasticity and measured service. And the three service models are software as a service (SaaS), Platform as a Service (PaaS) and Infrastructure as a Service (IaaS). It also can be the four deploy models; private, community, public, and hybrid." The characteristics were selected by customer demand and management capability of cloud computing technology. As for the cloud computing service model, software as a service (SaaS) is an application service delivered via cloud infrastructure, and this service is centrally provided and metered on a subscription basis [18]. Platform as a service (PaaS) offers development environments for computing platforms and solution stacks. It can run software solutions on a cloud computing platform without developer's service to provide hardware and software for the cloud computing system [19]. On the other hand, infrastructure as a service (IaaS) provides computing hardware like servers, virtual machines, networks, and storage, and system software including operating systems [20]. In recent years, a variety of cloud computing services have been provided.

Especially, an organization which wants to install a cloud computing infrastructure needs to consider the cloud computing deployment models. In this case they can select one of the four model types. Firstly, a private cloud provides computing services to an organizational unit and is available to members within a single organization. Its cloud system is located in its own data center or via an internet data center which is rented and operated on-premises by themselves or sometime managed by a third party [21]. Secondly, a community cloud provides computing services to facilitate collaboration for specific purposes such a mission, security, or compliance. Thirdly, a public cloud is not limited to use by one person or firm, and can be operated by a public cloud service provider like Amazon Web Services, Microsoft, and Sales Force [18,22]. Finally, there is a hybrid cloud model which is run by two or more model combinations [23]. It is growing in the market because companies need computing services that not only cover the globe without latency, but also has secure service without interruption [24].

Recently firms have begun to consider what is the right mix of IT systems and services to deploy hybrid IT in complex IT environments. So, the firms need a systematic approach to arrange the key models involved in the cloud computing system, and the IT value networks should be designed to successful management of the cloud computing system [14].

\subsection{Cloud Computing Adoption and Influence Factors}

Recently adopting a cloud computing system to address growing computing and storage challenges was rushed by governments, research institutes, and industry leaders [17]. Also cloud computing system was predicted as an inevitable future management tool for firms in new technology innovation environment [25]. The studies about cloud computing adoption analyzed and discussed the effectiveness and strategic alignment of cloud adoption [26], challenges, and issues like security, performance or integration, and cloud interoperability solutions [27]. And many researches evaluated the achievements or gaps in the success of cloud computing adoption $[10,16,24]$. Success factors and determinants of cloud computing adoption have particularly been the most popular in 
studies. Garrison et al. [28] studied success factors for deploying cloud computing; they found a relationship between trust, technical capability, managerial capability, and cloud-deployment performance. Low et al. [29] identified technological, organizational, and environmental contexts with factors which were proposed in prior studies to understand decision components of cloud adoption. Chen et al. [30] researched best-fitting models for adopting cloud services in an organization. Walther et al. [31] developed a measurement index for accessing cloud system success with system quality, information quality, and net benefits.

Low et al. [29] suggested an underlying model for cloud computing adoption which was validated by the TOE (technology, organization, environment) framework. After it developed between the moderating effects of IT governance structures and processed on these relationships in detail [32]. Alshamaila et al. [33] attempted to explore and develop an adoption model of cloud computing for small and medium business. Gangwar et al. [23] attempted to build a TAM(Technology Acceptance Model)-TOE framework for cloud computing adoption. Zardari and Bahsoon [34] suggested a goal-oriented approach for cloud adoption. The approach included requirements for engineering steps, categories of goals, and steps for cloud adoption. They proposed a toolkit that decision-makers can use to identify their risks and coordinate suitable tools and techniques [35]. A recent study of cloud adoption was conducted in terms of a national perspective and small and medium enterprises $[33,36,37]$, and the case studies described the direct influences of cloud computing on the organization in a wide range of activities, including global enterprises $[38,39]$.

The prior research indicated two things: First, various cloud computing adoption factors can be diversely assorted into technological, organizational, or environmental contexts. The second was that it pursued further understanding of the adoption of cloud computing factors in different industries. For example, Géczy et al. [40] proposed a model which had three main dimensions of cloud computing adoption concerns in alignment with the existing operation model in organizations, management and control of organizational data and services, and legal aspects. Low et al. [29] found that "relative advantage" of the technological context, "top management support" and "firm size" of organizational context, and "competitive pressure" and "trading partner pressure" of the environmental context were statistically a significant effect for the adoption of cloud computing in the high-tech industry. In addition, they understood that "compatibility", "complexity", and "technology readiness" were not identified as significant factors. In a goal-oriented approach, Zardari and Bahsoon [33] provided systematic guidance which was grounded in organization's weighing the choice and risks of adopting cloud computing. They emphasized establishing goals as an important factor. Within a resource-based theory view, Garrison, et al. [28] proposed a model of cloud deployment which emphasized organization specific capabilities including "technological infrastructure" and "technology support infrastructure relational resource". Khajeh-Hosseini et al. [35] emphasized that "cost" is one of the affecting factors for the adoption of cloud computing systems and developed a cost modelling tool.

Recent studies have considered "institutional factors", "efficiency", and "availability" in cloud computing desires as cloud computing adoption factors [24,41]. Bhat [36] suggested "laws and regulation" as the institutional factors. Besides, Yeboah-Boateng and Essandoh [37] mentioned the relative important influence of "adequate users and technical support" as the environmental factors. Oliveira et al. [11] created a model to assess the determinants which influence to adopt cloud computing, and presented the holistic assessment factors by the model. They identified "security concerns", "cost savings", "relative advantage", "complexity", "compatibility", "technology readiness", "top management support", "firm size", "competitive pressure", and "regulatory support" as factors. Based on this model, Gangwar et al. [23] suggested an organization's important determinants for adopting cloud computing were "relative advantage", "complexity", "compatibility", "ease of use", "usefulness", "top management commitment", "organizational readiness", "training and education", "competitive pressure", and "trading partner support". Gutierrez et al. [38] found that "complexity", "technology readiness", "competitive pressure", and "trading partner pressure" were decision-makers' 
affecting factors for cloud computing adoption. Ray [42] developed the four important focus areas for cloud computing adoption including reliability, security, vendor expertise, and availability.

\section{Research Method}

\subsection{Analytic Hierarchy Process (AHP)}

This research utilized the Delphi Analysis technique along with AHP (Analytic Hierarchy Process). In the two weeks in early August 2017, we conducted interviews with nine experts in Korea. First, key factors and attributes for deciding on cloud computing adoption derived from previous studies were analyzed to identify objective determinants using the Delphi technique and criteria set by five cloud computing professionals. In the process of deriving key determinants and strategic alternatives for cloud computing adoption, AHP analysis was used to arrive at the decision-making process. The decision making model was based on variables defined by AHP analysis, conceived and developed by Saaty [43]. Through hierarchical analysis on decision-making problems, AHP analysis offers the best alternative. This research used this process as a methodology for decision-making and for prioritizing processes, and through pairwise comparison of factors that compose the decision-making hierarchy, the knowledge, experience, and intuition of evaluators can be determined.

Through this process, AHP has proven beneficial for decision-making when the factors are difficult to measure. This research has eliminated the complexity among candidate factors of the technology area from the initial decision-making framework. In addition, it revised the security factors into the security concern attributes of the related advantage. Even with nine experts, AHP is a valid social science research method $[44,45]$. Also, the AHP method is commonly used not only in business management decision-making processes, but also in various information system research [46].

\subsection{Research Framework and Variables}

The decision-making framework to adopt cloud computing system was developed based on the TOE framework (Figure 1). The feature of this framework was designed as a three-tier architecture including decision areas, decision factors, and decision attributes to facilitate intuitive and rapid decision- making for decision-makers. All of the identified factors from prior research regarding cloud computing adoption were considered as options for the factors and attributes in the research model. Those factors were placed accordingly by nature into factors and attributes in the framework. Furthermore, we disregarded some factors like "complexity" and "firm size" in factors after reviewing with experts.

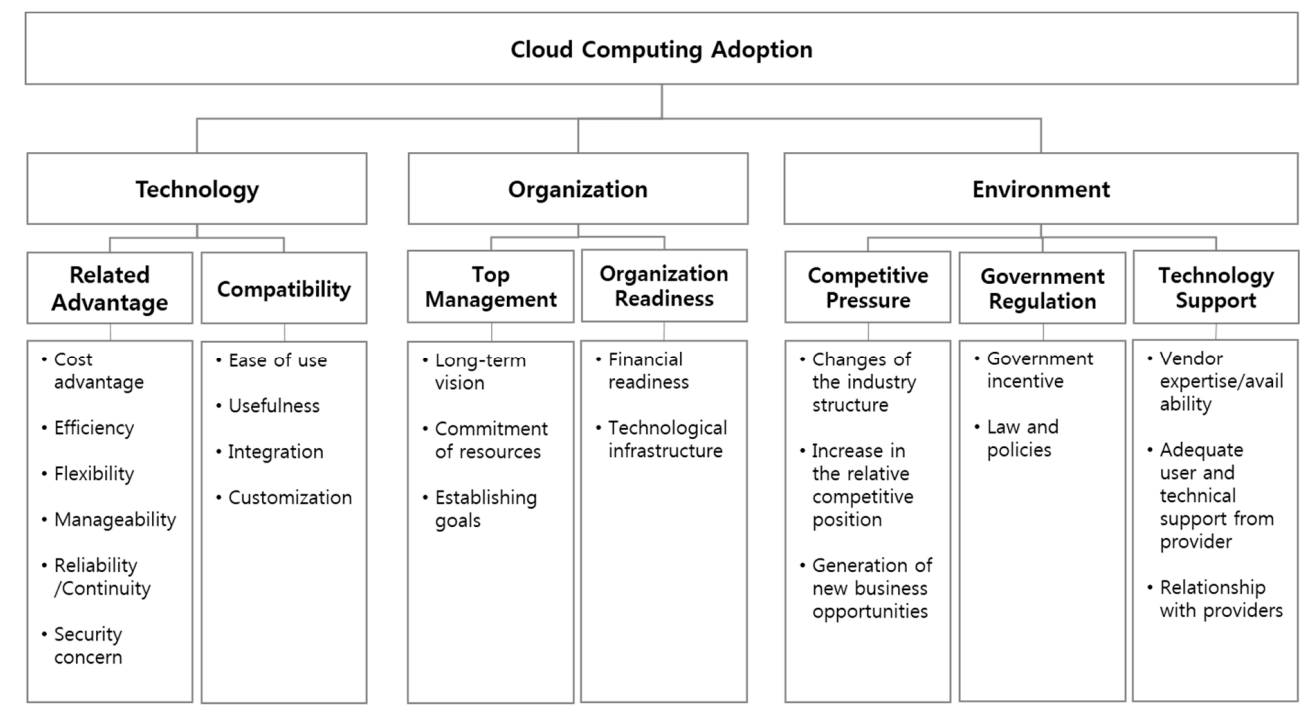

Figure 1. The decision-making hierarchy structure to adopt cloud computing system. 
The variables were grouped via the best-quoted research to determine the decision factors and attributes evaluated in related studies on cloud computing adoption. Each factor and attribute were examined to conclude their appropriateness for adopting a cloud computing system. Table 1 summarizes both the factors and attributes which were determined through this research approach.

Table 1. Decision Factors in Cloud Computing Adoption.

\begin{tabular}{|c|c|c|c|c|}
\hline Decision Area & Decision Factors & Decision Attributes & Definition & Related Reference \\
\hline \multirow{10}{*}{ Technology } & \multirow{6}{*}{ Related advantage } & Cost advantage & $\begin{array}{l}\text { Cost advantage, such as investment costs, } \\
\text { administrative costs, and operational costs }\end{array}$ & {$[10,26,28,47,48]$} \\
\hline & & Efficiency & Efficient utilization of IT resources & {$[24,26,39,49]$} \\
\hline & & Flexibility & $\begin{array}{l}\text { Flexibility of technical aspects, such as } \\
\text { automation of resource provisioning and refuges }\end{array}$ & {$[13,26,48]$} \\
\hline & & Manageability & $\begin{array}{l}\text { Simplicity of management, such as self-service } \\
\text { for end user and management automation }\end{array}$ & {$[28,48]$} \\
\hline & & Reliability/Continuity & $\begin{array}{l}\text { Improve reliability and continuity of business } \\
\text { services }\end{array}$ & {$[10,26,47,50]$} \\
\hline & & Security concern & Concern about security issue & [51] \\
\hline & \multirow{4}{*}{ Compatibility } & Ease of use & Convenience in use of cloud computing system & {$[10,24,26,48]$} \\
\hline & & Usefulness & The quality or fact of being useful & {$[24,26,39,49]$} \\
\hline & & Integration & $\begin{array}{l}\text { Interconnection and interoperability with legacy } \\
\text { system and system }\end{array}$ & \multirow{2}{*}{ [40] } \\
\hline & & Customization & $\begin{array}{l}\text { Ability to tailor services to suit business } \\
\text { conditions }\end{array}$ & \\
\hline \multirow{5}{*}{ Organization } & \multirow{3}{*}{$\begin{array}{l}\text { Top management } \\
\text { support }\end{array}$} & Long-term vision & $\begin{array}{l}\text { Long term vision for enterprise services and IT } \\
\text { infrastructure }\end{array}$ & {$[52,53]$} \\
\hline & & Commitment of resources & Assigning and allocating adequate resources & [54-56] \\
\hline & & Establishing goals & $\begin{array}{l}\text { Managing result of new IT adoption as key } \\
\text { performance factor }\end{array}$ & {$[34,57,58]$} \\
\hline & \multirow[b]{2}{*}{$\begin{array}{l}\text { Organization } \\
\text { readiness }\end{array}$} & Financial readiness & Preparation of budget and financial changes & [59] \\
\hline & & $\begin{array}{l}\text { Technological } \\
\text { infrastructure }\end{array}$ & $\begin{array}{l}\text { Understanding and preparing for the technical } \\
\text { preparations of the company and the skills of the } \\
\text { workforce }\end{array}$ & {$[60,61]$} \\
\hline \multirow{8}{*}{ Environment } & \multirow{3}{*}{$\begin{array}{l}\text { Competitive } \\
\text { pressure }\end{array}$} & $\begin{array}{l}\text { Changes of the industry } \\
\text { structure }\end{array}$ & The adaptation to changes of industrial structure & \multirow{3}{*}[62,63]{} \\
\hline & & $\begin{array}{l}\text { Increases in the relative } \\
\text { competitive position }\end{array}$ & $\begin{array}{l}\text { The need to gain a competitive edge in a } \\
\text { competitive industry }\end{array}$ & \\
\hline & & $\begin{array}{c}\text { Generation of new } \\
\text { business opportunities }\end{array}$ & The need for new business development & \\
\hline & \multirow{2}{*}{$\begin{array}{l}\text { Government } \\
\text { regulation }\end{array}$} & Government incentive & $\begin{array}{l}\text { The Impact of government cloud computing } \\
\text { service promotion system (government tax } \\
\text { discounts and subsidies) }\end{array}$ & [64] \\
\hline & & Law and policy & $\begin{array}{c}\text { Impact of applicable laws and policies (Cloud } \\
\text { Computing Development Act) }\end{array}$ & [65] \\
\hline & \multirow{3}{*}{$\begin{array}{l}\text { Technology } \\
\text { support } \\
\text { infrastructure }\end{array}$} & $\begin{array}{c}\text { Vendor } \\
\text { expertise/availability }\end{array}$ & $\begin{array}{l}\text { Technical expertise and service availability of } \\
\text { cloud computing service providers }\end{array}$ & [25] \\
\hline & & $\begin{array}{l}\text { Adequate user and } \\
\text { technical support from } \\
\text { provider }\end{array}$ & $\begin{array}{l}\text { Referenceable adequate user and service } \\
\text { provider's technical support capability }\end{array}$ & \multirow[t]{2}{*}{ [41] } \\
\hline & & $\begin{array}{l}\text { Relationship with } \\
\text { providers }\end{array}$ & Strategic partnership with provider & \\
\hline
\end{tabular}

\subsection{Data Collection}

The data were collected in August and September 2017 through interviews in person. One interview via email with a resident overseas was conducted. The survey participants' detailed demographic information is presented in Table 2. We selected 20 respondents who are experts in novel technology adoption and have experience in cloud computing system adoption in organizations. We divided 20 respondents into 10 demanders and 10 providers. Twenty respondents who had more than fifteen years of experience in information technology (IT) related tasks were selected. We selected 10 demanders who have both experienced and have participated in cloud computing adoption decision activities in the field of finance, manufacturing, and communication industries. We selected 10 service providers who are experts in delivering cloud computing services at global cloud computing service 
companies (Hewlett Packard Enterprise, Microsoft, Cisco, and Symantec) and several local companies in South Korea.

Table 2. Demographic Information.

\begin{tabular}{|c|c|c|c|}
\hline Section & Characteristics & Frequency & Ratio (\%) \\
\hline \multirow{3}{*}{ Work experience in the related field } & $15-20$ years & 8 & 40 \\
\hline & $20-25$ years & 6 & 30 \\
\hline & Over 25 years & 6 & 30 \\
\hline \multirow{8}{*}{ Professional area } & Application manager & 1 & 5 \\
\hline & System engineer & 1 & 5 \\
\hline & IT Infrastructure operating manager & 2 & 10 \\
\hline & IT architect & 3 & 15 \\
\hline & IT planning team leader & 4 & 20 \\
\hline & IT project manager & 2 & 10 \\
\hline & IT consultant & 5 & 25 \\
\hline & IT sales & 2 & 10 \\
\hline \multirow{2}{*}{ Highest education received } & Bachelor's degree & 14 & 70 \\
\hline & Master's degree & 6 & 30 \\
\hline \multirow{2}{*}{ Age } & $40-50$ years & 17 & 85 \\
\hline & Over 50 year & 3 & 25 \\
\hline \multirow{2}{*}{ Gender } & Male & 18 & 90 \\
\hline & Female & 2 & 10 \\
\hline \multirow{2}{*}{ Role and responsibility } & Cloud computing demander & 10 & 50 \\
\hline & Cloud computing provider & 10 & 50 \\
\hline
\end{tabular}

Regarding previous studies which surveyed 10 pundits on the sue of AHP to analyze success factors in internet service adoption [66], this research, with more than 20 experts, is statistically reliable. The current research asked for surveys from various respondents from these following professional categories: (1) application manager, (2) systems engineer, (3) IT Infrastructure operating manager, (4) IT architect, (5) IT planning team leader, (6) IT project manager, (7) IT consultant, and (8) IT sales. These categorizations were classified for validating respondent's opinions to adopt a cloud computing system in a firm. The age distribution of the respondents was $85 \%$ in their $40 \mathrm{~s}$ and $15 \%$ in their $50 \mathrm{~s}$. The respondents' education background was 70\% bachelor's degree and 30\% master's degree. The gender distribution was $90 \%$ male and $10 \%$ female.

The weights were evaluated using an AHP Excel template which was provided by Business Performance Management Singapore (BPMSG) and was used under MS Excel 2013 on Windows 10. The template provided pair-wise comparisons, consolidation of all judgments, and the results, and used row geometric mean method (RGMM) for calculating priorities and eigenvector method (EVM) for solving eigenvalue problem. The responders' consistency ratio (CR) for all questionnaires was less than 0.1. Values less than 0.1 indicate that the answers were both logically consistent and meaningful (Related Advantage: 0.013, Compatibility: 0.016, Top Management Support: 0.000, Organization Readiness: 0.001, Competitive Pressure: 0.005, Government Regulation: 0.001, Technology Support Infrastructure: 0.001) [67].

The current research proceeded with pairwise comparison and computation of the area, factor, and attribute weightings with four steps [68]. First, the relative importance of each decision area, each factor, and each attribute was decided after computing the different weights through pairwise comparisons. Second, a vector of priorities was computed. Third the consistency of the judgment in each response was determined. Finally, we analyzed the relative importance after dividing respondents into demanders and providers. 


\section{Analysis Results}

\subsection{Comparison of the Evaluation Factors}

As per Table 3, we analyzed the weights of the factors and contributions from a comprehensive perspective including demanders and providers, and it presents composite weights and priority of the decision areas, factors, and attributes for adopting a cloud computing system. The local means the weight which measured the priorities among each decision areas, factors, and attributes. The global means the weight which measured integrally the priorities of all decision areas, factors, and attributes in the framework. From a Korean enterprise cloud computing adoption expert's point of view, the environment area had become the top priority with 0.38618 . The organization area (0.34116) was the second highest priority, and the technology area (0.27265) had the lowest priority among the decision areas. Among the decision factors, the Top Management Support factor had become the top priority with 0.21190 . The Competitive Pressure factor $(0.17662)$ had second priority. The Compatibility factor (0.17437) was the third priority. The Organization Readiness factor $(0.12910)$ was fourth highest. The Government Regulation factor (0.10887) was the fifth highest priority, while the Related Advantage factor (0.09816) had the lowest priority. Top Management Support was a significant factor for adopting a cloud computing system, as seen in previous studies [23,29]. However, Compatibility did not correspond to a previous study [11,29]. This finding implies that when decision-makers in South Korea decide to adopt a cloud computing system, they consider that compatibility with existing systems is important to maintain the stability of the legacy system. Low et al. [29] thought that negative influence was a possibility for the Relative Advantage because of complex charging mechanisms. But Relative Advantage was not regarded as a negative influence or a barrier to adopting cloud computing in this study.

Among the decision attributes, the Increases in the Relative Competitive Position attribute had become the top priority with 0.08889 . The Long-Term Vision attribute $(0.08084)$ had second priority. The Commitment of Resources attribute (0.07784) was the third highest. The Law and Policy attribute (0.06867) was fourth highest. The Technological Infrastructure attribute $(0.06458)$ was the fifth highest priority, and the Cost Benefit attribute (0.00736) had the lowest priority. The results of the priority of decision attributes came from decision-makers seeking to gain a sustainable competitive edge in their organization through the adoption of cloud computing system. And the Law and Policy attributes show that the South Korea government's cloud development act $[5,6]$ has affected decision-makers who are considering introducing cloud computing. Furthermore, Technological Infrastructure was also regarded as an important attribute unlike previous findings [29]. 
Table 3. The weights and priority of the decision areas, factors, and attributes for cloud computing adoption.

\begin{tabular}{|c|c|c|c|c|c|c|c|c|c|}
\hline \multirow{2}{*}{$\begin{array}{l}\text { Decision } \\
\text { Areas }\end{array}$} & \multirow{2}{*}{$\begin{array}{c}\text { The Weights } \\
\text { of Areas }\end{array}$} & \multirow{2}{*}{ Decision Factors } & \multicolumn{2}{|c|}{ The Weights of Factors } & \multirow{2}{*}{$\begin{array}{l}\text { Priority of } \\
\text { Factors }\end{array}$} & \multirow[t]{2}{*}{ Decision Attributes } & \multicolumn{2}{|c|}{$\begin{array}{l}\text { The Weights of } \\
\text { Attributes }\end{array}$} & \multirow{2}{*}{$\begin{array}{l}\text { Priority of } \\
\text { Attributes }\end{array}$} \\
\hline & & & Local & Global & & & Local & Global & \\
\hline \multirow{10}{*}{ Technology } & \multirow{10}{*}{0.27265} & \multirow{6}{*}{ Related Advantage } & \multirow{6}{*}{0.36001} & \multirow{6}{*}{0.09816} & \multirow{6}{*}{7} & Cost benefit & 0.12237 & 0.01201 & 20 \\
\hline & & & & & & Efficiency & 0.13657 & 0.01341 & 19 \\
\hline & & & & & & Flexibility & 0.10819 & 0.01062 & 21 \\
\hline & & & & & & Manageability & 0.07498 & 0.00736 & 22 \\
\hline & & & & & & Reliability/continuity & 0.25905 & 0.02543 & 18 \\
\hline & & & & & & Security Concern & 0.19883 & 0.02933 & 17 \\
\hline & & \multirow{4}{*}{ Compatibility } & \multirow{4}{*}{0.63954} & \multirow{4}{*}{0.17437} & \multirow{4}{*}{3} & Ease of Use & 0.21670 & 0.03779 & 13 \\
\hline & & & & & & Usefulness & 0.35970 & 0.06272 & 8 \\
\hline & & & & & & Integration & 0.22269 & 0.03883 & 12 \\
\hline & & & & & & Customization & 0.20092 & 0.03503 & 15 \\
\hline \multirow{4}{*}{ Organization } & \multirow{4}{*}{0.34116} & \multirow{2}{*}{$\begin{array}{l}\text { Top Management } \\
\text { Support }\end{array}$} & \multirow[b]{2}{*}{0.62113} & \multirow[b]{2}{*}{0.21190} & \multirow[b]{2}{*}{1} & Long-term Vision & 0.38151 & 0.08084 & 2 \\
\hline & & & & & & Commitment of Resources & 0.36733 & 0.07784 & 3 \\
\hline & & \multirow{2}{*}{ Organization Readiness } & \multirow{2}{*}{0.37841} & \multirow{2}{*}{0.12910} & \multirow{2}{*}{4} & Financial Readiness & 0.49930 & 0.06446 & 6 \\
\hline & & & & & & Technological Infrastructure & 0.50021 & 0.06458 & 5 \\
\hline \multirow{7}{*}{ Environment } & \multirow{7}{*}{0.38618} & \multirow{3}{*}{ Competitive Pressure } & \multirow{3}{*}{0.45736} & & & Change of the Industry Structure & 0.24937 & 0.04369 & 10 \\
\hline & & & & 0.17662 & 2 & $\begin{array}{l}\text { Increases in the Relative } \\
\text { Competitive Position }\end{array}$ & 0.24734 & 0.08889 & 1 \\
\hline & & & & & & $\begin{array}{l}\text { Generation of New Business } \\
\text { Opportunities }\end{array}$ & 0.50329 & 0.03433 & 16 \\
\hline & & Government Reoulation & 028191 & 010887 & 5 & Government Incentive & 0.36874 & 0.04014 & 11 \\
\hline & & & 0.28191 & $0.1088 \%$ & 5 & Law and Policy & 0.63081 & 0.06867 & 4 \\
\hline & & & & & & Vendor Expertise/Availability & 0.62460 & 0.06289 & 7 \\
\hline & & Infrastructure & 0.26073 & 0.10069 & 6 & $\begin{array}{l}\text { Adequate User and Technological } \\
\text { Support from Provide }\end{array}$ & 0.37494 & 0.03775 & 14 \\
\hline
\end{tabular}




\subsection{Comparison Analysis of Decision Factors}

The decision factors have been analyzed for the difference in the priorities of decision factors for enterprise cloud computing adoption between demander and provider. In contrast to Table 3, Table 4 presents the comparison results of decision factors for enterprise cloud computing adoption, and different points of views from each demander's and provider's side. From the perspective of provider, the Related Advantage factor was the top priority with 0.78120. The Top Management Support factor (0.34747) was the second highest priority; the Competitive Pressure factor (0.17204) was third highest; the Organization Readiness factor (0.13660) was fourth highest; the Compatibility factor (0.12372) was the fifth highest priority, and the Technology Support Infrastructure factor (0.06009) had the lowest priority among the decision factors. From the perspective of demander, the Compatibility factor was the top priority with 0.22608 . The Competitive Pressure factor $(0.14770)$ was the second highest priority; the Technology Support Infrastructure factor (0.14761) was third highest; the Government Regulation factor (0.13008) was fourth highest; the Top Management Support factor (0.11401) was the fifth highest priority, and the Organization Readiness factor (0.10764) had the lowest priority among the decision factors.

Table 4. The comparison results of decision factors for cloud computing adoption between demander and provider.

\begin{tabular}{ccccc}
\hline \multirow{2}{*}{ Decision Factors } & \multicolumn{2}{c}{ Demander } & \multicolumn{2}{c}{ Provider } \\
\cline { 2 - 5 } & The Weights (Mean) & Priority & The Weights (Mean) & Priority \\
\hline Related Advantage & 0.11345 & 6 & 0.78120 & 1 \\
Compatibility & 0.22608 & 1 & 0.12372 & 5 \\
Top Management Support & 0.11401 & 5 & 0.34747 & 2 \\
Organization Readiness & 0.10764 & 7 & 0.13660 & 4 \\
Competitive Pressure & 0.14770 & 2 & 0.17204 & 3 \\
Government Regulation & 0.13008 & 4 & 0.08083 & 6 \\
Technology Support Infrastructure & 0.14761 & 3 & 0.06009 & 7 \\
\hline
\end{tabular}

These findings suggest that the Competitive Pressure was a significant factor for both provider and demander. However, the Relative Advantage and the Top Management Support factors in provider's decision factors indicate that providers are more likely to focus on the benefits of adopting cloud computing systems, and that top management has a lot of influence on decision-making of the provider [4]. When it comes to adopting cloud computing, demanders are more likely than providers to seek for system stability and upgrade without making massive changes to the legacy system, and they are prone to adopt cloud computing systems to gain high competitiveness.

\subsection{Comparison Analysis of Decision Attributes}

This research analyzed the difference in priorities of decision attributes of enterprise cloud computing adoption between demanders and providers. Table 5 presents the comparison results of decision attributes of enterprise cloud computing adoption between demander and provider. From the perspective of providers, the Long-term Vision attribute had become the top priority with 0.14913 . The Commitment of Resources attribute (0.13755) was the second highest priority; the Generation of New Business Opportunities attribute (0.09763) was the third highest; the Financial Readiness attribute (0.08915) was fourth highest; the Establishing Goal attribute (0.06079) was the fifth highest priority, and the Manageability attribute (0.00778) had the lowest priority. From the perspective of demander, the Vendor Expertise/Availability attribute was the top priority with 0.10735 . The Law and Policy attribute (0.08294) was the second highest priority; the Usefulness attribute (0.08280) was third highest; the Technological Infrastructure attribute (0.07034) was fourth highest; the Generation of New Business Opportunities attribute (0.06408) was the fifth highest priority, and the Manageability attribute (0.00851) had the lowest priority. 
Table 5. The comparison results of decision attributes for cloud computing adoption between demander and provider.

\begin{tabular}{|c|c|c|c|c|c|}
\hline \multirow[b]{2}{*}{ Decision Factors } & \multirow[b]{2}{*}{ Decision Attributes } & \multicolumn{2}{|c|}{ Demander } & \multicolumn{2}{|c|}{ Provider } \\
\hline & & $\begin{array}{l}\text { The Weights } \\
\text { (Mean) }\end{array}$ & Priority & $\begin{array}{l}\text { The Weights } \\
\text { (Mean) }\end{array}$ & Priority \\
\hline \multirow{6}{*}{ Related Advantage } & Cost benefit & 0.01388 & 20 & 0.01872 & 17 \\
\hline & Efficiency & 0.01549 & 19 & 0.01351 & 19 \\
\hline & Flexibility & 0.01228 & 21 & 0.01058 & 21 \\
\hline & Manageability & 0.00851 & 22 & 0.00778 & 22 \\
\hline & Reliability/continuity & 0.02939 & 18 & 0.01102 & 20 \\
\hline & Security Concern & 0.03390 & 17 & 0.01653 & 18 \\
\hline \multirow{4}{*}{ Compatibility } & Ease of Use & 0.05291 & 6 & 0.02482 & 16 \\
\hline & Usefulness & 0.08280 & 3 & 0.04361 & 8 \\
\hline & Integration & 0.05124 & 7 & 0.02692 & 15 \\
\hline & Customization & 0.03914 & 12 & 0.02836 & 14 \\
\hline \multirow{3}{*}{$\begin{array}{c}\text { Top Management } \\
\text { Support }\end{array}$} & Long-term Vision & 0.03716 & 15 & 0.14913 & 1 \\
\hline & Commitment of Resources & 0.03735 & 13 & 0.13755 & 2 \\
\hline & Establishing Goal & 0.03952 & 11 & 0.06079 & 5 \\
\hline Organization & Financial Readiness & 0.03725 & 14 & 0.08915 & 4 \\
\hline Readiness & Technological Infrastructure & 0.07034 & 4 & 0.04739 & 7 \\
\hline \multirow{3}{*}{$\begin{array}{l}\text { Competitive } \\
\text { Pressure }\end{array}$} & Change of the Industry Structure & 0.04794 & 8 & 003204 & 10 \\
\hline & $\begin{array}{l}\text { Increases in the Relative } \\
\text { Competitive Position }\end{array}$ & 0.03567 & 16 & 0.04236 & 9 \\
\hline & $\begin{array}{l}\text { Generation of New Business } \\
\text { Opportunities }\end{array}$ & 0.06408 & 5 & 0.09763 & 3 \\
\hline \multirow{2}{*}{$\begin{array}{l}\text { Government } \\
\text { Regulation }\end{array}$} & Government Incentive & 0.04708 & 9 & 0.03036 & 12 \\
\hline & Law and Policy & 0.08294 & 2 & 0.05043 & 6 \\
\hline \multirow{2}{*}{$\begin{array}{l}\text { Technology Support } \\
\text { Infrastructure }\end{array}$} & Vendor Expertise/Availability & 0.10735 & 1 & 0.03103 & 11 \\
\hline & $\begin{array}{l}\text { Adequate User and Technological } \\
\text { Support from Provide }\end{array}$ & 0.0420 & 10 & 0.02986 & 13 \\
\hline
\end{tabular}

The Vendor Expertise/Availability was the highest attribute of demanders. This is consistent with the results of a previous study that the trust between client organization and cloud provider was a significant success factor of cloud computing deployment [28]. It explains that trust and a relationship with a service provider are important for deciding a service adoption in the IT industry. Providers selected Long-Term Vision as the highest attribute. South Korea enterprises tend to make a short-term plan and frequent plan changes because they are sensitive to government regulations [4] and financial effects [5]. But cloud computing adoption and system management need a clear vision and long-term plan for a successful performance. In this discussion, the results highlight the importance of Long-Term Vision to adopt cloud computing services.

\section{Conclusions}

Understanding the priorities of decision factors and attributes to adopt cloud computing systems is meaningful when organizations ultimately analyze the adoption processes of cloud computing for a firm's successful digital transformation. The research results show that the demander placed more priority on the environment area, and the provider gave higher priority to the organization area. It means that the demander is mostly affected by external environmental conditions of the firm, and the provider can recognize that the internal factors of the firm have the biggest influence. In terms of a full sample, Table 3 represents the integral perspective of demander and provider, it places great importance on Top Management Support, Competitive Pressure, and Compatibility in that order. 
By comparison with Table 3, Table 4 indicates a distinctive perspective of two different positions: demander and provider. Resultantly, demanders' high priorities as decision factors are Compatibility, Competitive Pressure, and Technology Support Infrastructure; on the other hand, the important factors to adopt cloud computing system of providers were Related Advantage, Top Management Support, and Competitive Pressure.

It explains that top management support is a very powerful influencing factor for adopting and decides the cloud computing system within an organization. When companies adopt new technologies, they can see that top-down approaches to decisions still play an important role. The demander chose compatibility as the highest priority of cloud computing adoption factors. It shows the demander is concerned with the most crucial aspect of the stable operation of existing legacy systems and services. By contrast, related advantage is prioritized the highest by the provider. It means the provider appreciate the best benefits of adopting cloud computing for their businesses.

With previous studies, the critical decision factors affecting the successful cloud computing service adoption mentioned were "government regulation and organizational environment" [4], "financial readiness and cost" [5], and "usefulness" [6]. But this analysis' results indicate Increases in the Relative Competitive Position, Long-Term Vision, Commitment of Resources, Government Incentive, and Law and Policy as the important decision attribute factors to adopt a cloud computing system. Thus, it clearly demonstrates that various corporations highly consider regarding competitive environments to develop their competitiveness with a digital transformation. Companies depend on top management support even if they have a cloud computing system. On the demander side, Vendor Expertise, Availability, Law and Policy, Usefulness, and Technological Infrastructure were valuable factors to adopt cloud computing systems, and it shows that demanders are more sensitive to law and policy than providers and on focused reliability value to consider their cloud computing adoption. But the priority of the decision attributes for providers was in the following order: Long-Term Vision, Commitment of Resources, Generation of New Business Opportunities, Financial Readiness, and Establishing Goals. It means that providers highly consider about goal consciousness and resources to gain momentum for cloud computing adoption.

Consequentially this study demonstrates that identified decision areas, factors, and attributes of the decision-making model influence firm's decision-making to adopt cloud computing systems. Most of all, this research has defined the important factors based on previous studies and the TOE framework to manage cloud computing services and systems. As a developed structural decision-making model for cloud computing services and management rather than the previously presented models, it supports decision-makers to make the right decision of whether to adopt cloud computing quickly based on priorities in a decision-making model, taking into consideration the current technology, organization, and environmental situation. The comparison analysis results show that demander and provider have different needs and decision concepts of whether to adopt or manage their cloud computing service. Finally, this study proposes to extend the decision-making model to take into consideration things such as the organization's requirements and capabilities for the cloud computing management.

However, the research needs further research based on comprehensive analyses from various countries and conglomerates to define the general factors and the decision model for the cloud computing management because this study just collected the data by face to face interviews from 12 experts in South Korean companies. And even though this research measured the importance of each areas, factors, and attributes in three categories for the cloud computing adoption, more empirical studies need to figure out the practicality and specificity of the cloud computing.

Author Contributions: All authors conceived and designed the idea of the paper: S.-K.Y. collected survey and analyzed the data and B.-Y.K. reviewed related previous literature. All authors also wrote and reviewed the manuscript.

Acknowledgments: This research was supported by Seoul School of Integrated Sciences and Technologies (aSSIST). 
Conflicts of Interest: The authors declare no conflict of interest.

\section{References}

1. World-Economic-Forum. Digital Transformation Initiative. Available online: https://www.weforum.org/ whitepapers / digital-transformation-initiative (accessed on 21 December 2017).

2. Gantz, J.F.; Miller, P. The Salesforce Economy: Enabling 1.9 Million New Jobs and \$389 Billion in New Revenue Over the Next Five Years. Available online: http:/ / www.salesforce.com/assets/pdf/misc/IDCsalesforce-economy-study-2016.pdf (accessed on 3 October 2017).

3. Korea National Computing \& Information Agency. G-Cloud Start G-Cloud Service from 2011. Available online: http:/ / www.ncia.go.kr/newsletter/2011-18/sub/topic02.html (accessed on 5 August 2018).

4. Kim, T.; Hwang, S.; Suh, S.; Kim, D. A Study on Building a Cloud System for Local Government. J. Korean Assoc. Reg. Inf. Soc. 2015, 18, 34-47.

5. Do, H.-J.; Kim, I.-S. A Study on Cloud Computing for Financial Sector limited to Processing System of Non-Critical Information: Policy Suggestion based on US and UK's approach. J. Soc. e-Bus. Stud. 2017, 22, $39-51$.

6. Lee, J.K.; Min, D.; Kwon, H.Y. Issues and Suggestions for "Act on the Development of Cloud Computing" and Protection of its Users. J. Inf. Technol. Appl. Manag. 2017, 24, 81-91.

7. International Data Group (IDG). Current Cloud in Korea in 2017. Available online: http:/ /www.itworld.co. $\mathrm{kr} /$ techlibrary/103142 (accessed on 5 August 2018).

8. Bloem, J.; Van Doorn, M.; Duivestein, S.; Excoffier, D.; Maas, R.; Van Ommeren, E. The Fourth Industrial Revolution-Things to Tighten the Link between IT and OT; Sogeti Vint: Paris, France, 2014.

9. Schwab, K. The Fourth Industrial Revolution; Crown Business: New York, NY, USA, 2017.

10. Yang, H.; Tate, M. A descriptive literature review and classification of cloud computing research. Commun. Assoc. Inf. Syst. 2012, 31, 2-26.

11. Oliveira, T.; Thomas, M.; Espadanal, M. Assessing the determinants of cloud computing adoption: An analysis of the manufacturing and services sectors. Inf. Manag. 2014, 51, 497-510. [CrossRef]

12. Buyya, R.; Yeo, C.S.; Venugopal, S.; Broberg, J.; Brandic, I. Cloud computing and emerging IT platforms: Vision, hype, and reality for delivering computing as the 5th utility. Future Gener. Comput. Syst. 2009, 25, 599-616. [CrossRef]

13. Armbrust, M.; Fox, A.; Griffith, R.; Joseph, A.D.; Katz, R.H.; Konwinski, A.; Stoica, I. Above the Clouds: A Berkeley View of Cloud Computing. Available online: https://www2.eecs.bere/EECS-2009-28.pdf (accessed on 21 December 2017).

14. Morgan, L.; Conboy, K. Factors Affecting the Adoption of Cloud Computing: An Exploratory Study. In Proceedings of the 21st European Conference on Information Systems (ECIS), Utrecht, The Netherlands, 6-8 June 2013.

15. Weiss, A. Computing in the clouds. Network 2007, 11, 16-25. [CrossRef]

16. Dahlberg, T.; Kivijärvi, H.; Saarinen, T. Longitudinal Study on the Expectations of Cloud Computing Benefits and an Integrative Multilevel Model for Understanding Cloud Computing Performance. In Proceedings of the 50th Hawaii International Conference on System Sciences, Waikoloa, HI, USA, 4-7 January 2017.

17. Foster, I.; Zhao, Y.; Raicu, I.; Lu, S. Cloud Computing and Grid Computing 360-Degree Compared. In Proceedings of the Grid Computing Environments Workshop, Austin, TX, USA, 16 November 2008.

18. Mell, P.; Grance, T. The NIST definition of cloud computing. Commun. ACM 2011, 53. [CrossRef]

19. Butler, B. PaaS Primer: What Is Platform as a Service and Why Does It Matter? 2013. Available online: https:// www.networkworld.com/article/2163430/cloud-computing/paas-primer--whatis-platform-as-a-service-and-why-does-it-matter-.html (accessed on 5 August 2018).

20. Bhardwaj, S.; Jain, L.; Jain, S. Cloud computing: A study of infrastructure as a service (IAAS). Int. J. Eng. Inf. Technol. 2010, 2, 60-63.

21. Jadeja, Y.; Modi, K. Cloud computing-concepts, architecture and challenges. In Proceedings of the 2012 International Conference Computing, Electronics and Electrical Technologies (ICCEET), Nagercoil, India, 21-22 March 2012.

22. Rimal, B.P.; Choi, E.; Lumb, I. A Taxonomy and Survey of Cloud Computing Systems. In Proceedings of the 2009 Fifth International Joint Conference on INC, IMS and IDC, Washington, DC, USA, 25-27 August 2009. 
23. Gangwar, H.; Date, H.; Ramaswamy, R. Understanding determinants of cloud computing adoption using an integrated TAM-TOE model. J. Enterp. Inf. Manag. 2015, 28, 107-130. [CrossRef]

24. Venters, W.; Whitley, E.A. A critical review of cloud computing: Researching desires and realities. J. Inf. Technol. 2012, 27, 179-197. [CrossRef]

25. Kim, W.; Kim, S.D.; Lee, E.; Lee, S. Adoption issues for cloud computing. In Proceedings of the 7th International Conference on Advances in Mobile Computing and Multimedia, Kuala Lumpur, Malaysia, 14-16 December 2009.

26. Chebrolu, S.B. Assessing the relationships among cloud adoption, strategic alignment and IT effectiveness. J. Inf. Technol. Manag. 2011, 22, 13-29.

27. Dillon, T.; Wu, C.; Chang, E. Cloud computing: Issues and challenges. In Proceedings of the Advanced Information Networking and Applications (AINA): 24th IEEE International Conference, Perth, Australia, 20-23 April 2010.

28. Garrison, G.; Kim, S.; Wakefield, R.L. Success factors for deploying cloud computing. Commun. ACM 2012, 55, 62-68. [CrossRef]

29. Low, C.; Chen, Y.; Wu, M. Understanding the determinants of cloud computing adoption. Ind. Manag. Data Syst. 2011, 111, 1006-1023. [CrossRef]

30. Chen, S.L.; Chen, J.H.; Lee, Y.H. A comparison of competing models for understanding industrial organization's acceptance of cloud services. Sustainability 2018, 10, 673. [CrossRef]

31. Walther, S.; Sedera, D.; Sarker, S.; Eymann, T. Evaluating Operational Cloud Enterprise System Success: An Organizational Perspective. In Proceedings of the 21st European Conference on Information Systems, Utrecht, The Netherlands, 6-8 June 2013.

32. Borgman, H.P.; Bahli, B.; Heier, H.; Schewski, F. Cloudrise: Exploring cloud computing adoption and governance with the TOE framework. In Proceedings of the 2013 46th Hawaii International Conference on System Sciences, Wailea, Maui, HI, USA, 7-10 January 2013.

33. Alshamaila, Y.; Papagiannidis, S.; Li, F. Cloud computing adoption by SMEs in the north east of England: A multi-perspective framework. J. Enterp. Inf. Manag. 2013, 26, 250-275. [CrossRef]

34. Zardari, S. Cloud Adoption: A Goal-Oriented Requirements Engineering Approach. Ph.D. Thesis, The University of Birmingham, Birmingham, UK, 2016.

35. Khajeh-Hosseini, A.; Greenwood, D.; Smith, J.W.; Sommerville, I. The cloud adoption toolkit: Supporting cloud adoption decisions in the enterprise. Softw. Pract. Exp. 2012, 42, 447-465. [CrossRef]

36. Bhat, J.M. Adoption of cloud computing by SMEs in India: A study of the institutional factors. In Proceedings of the Nineteenth Americas Conference on Information Systems, Chicago, IL, USA, 15-17 August 2013.

37. Gutierrez, A.; Boukrami, E.; Lumsden, R. Technological, organizational and environmental factors influencing managers' decision to adopt cloud computing in the UK. J. Enterp. Inf. Manag. 2015, 28, 788-807. [CrossRef]

38. Schlagwein, D.; Thorogood, A.; Willcocks, L.P. How Commonwealth Bank of Australia Gained Benefits Using a Standards-Based, Multi-Provider Cloud Model. MIS Q. Exec. 2014, 13, 34-56.

39. Winkler, T.J.; Benlian, A.; Piper, M.; Hirsch, H. Bayer HealthCare Delivers a Dose of Reality for Cloud Payoff Mantras in Multinationals. MIS Q. Exec. 2014, 13, 45-103.

40. Géczy, P.; Izumi, N.; Hasida, K. Cloudsourcing: Managing Cloud Adoption; National Institute of Advanced Industrial Science and Technology (AIST): Tokyo, Japan, 2011.

41. Yeboah-Boateng, E.O.; Essandoh, K.A. Factors influencing the adoption of cloud computing by small and medium enterprises in developing economies. Intern. J. Emerg. Sci. Eng. 2014, 2, 13-20.

42. Ray, D. Cloud Adoption Decisions: Benefitting from an Integrated Perspective. Electron. J. Inf. Syst. Eval. 2016, 19, 212-245.

43. Saaty, T.L. The Analytic Hierarchy Process: Planning. Priority Setting. Resource Allocation; MacGraw-Hill: New York, NY, USA; International Book Company: New York, NY, USA, 1980.

44. Ngai, E. Selection of web sites for online advertising using the AHP. Inf. Manag. 2003, 40, 233-242. [CrossRef]

45. Van Laarhoven, P.; Pedrycz, W. A fuzzy extension of Saaty's priority theory. Fuzzy Sets Syst. 1983, 11, $229-241$. [CrossRef]

46. Wu, H.D. Systemic determinants of international news coverage: A comparison of 38 countries. J. Commun. 2000, 20, 110-130. [CrossRef] 
47. Zhang, Q.; Cheng, L.; Boutaba, R. Cloud computing: State-of-the-art and research challenges. J. Intern. Serv. Appl. 2010, 1, 7-18. [CrossRef]

48. Zissis, D.; Lekkas, D. Is cloud computing finally beginning to mature? Intern. J. Cloud Comput. Serv. Sci. 2012, 1, 172. [CrossRef]

49. Sultan, N.A. Reaching for the "cloud": How SMEs can manage. Intern. J. Inf. Manag. 2011, 31, $272-278$. [CrossRef]

50. Iyer, B.; Henderson, J.C. Business Value from Clouds: Learning from Users. MIS Q. Exec. 2012, 11, 12-32.

51. Gonzalez, N.; Miers, C.; Redigolo, F.; Simplicio, M.; Carvalho, T.; Näslund, M.; Pourzandi, M. A quantitative analysis of current security concerns and solutions for cloud computing. J. Cloud Comput. Adv. Syst. Appl. 2012, 1, 11-25. [CrossRef]

52. Lee, S.; Kim, K.J. Factors affecting the implementation success of Internet-based information systems. Comput. Hum. Behav. 2007, 23, 1853-1880. [CrossRef]

53. Pyke, J. Now Is the Time to Take the Cloud Seriously. White Paper. Available online: https:/ / www.cordys.com/cordyscms_sites/objects/bb1a0bd7f47b1c91ddf36ba7db88241d/time_to_ take_the_cloud_seroiusly_online_1_.pdf (accessed on 21 December 2017).

54. Keen, P.G.; Bronsema, G.S.; Zuboff, S. Implementing Common Systems: One Organization's Experience; Sloan School of Management: Cambridge, MA, USA, 1981.

55. Schultz, R.L.; Slevin, D.P.; Pinto, J.K. Strategy and tactics in a process model of project implementation. Interfaces 1987, 17, 34-46. [CrossRef]

56. Tyran, C.K.; George, J.F. The implementation of expert systems: A survey of successful implementations. ACM SIGMIS Database 1993, 24, 5-15. [CrossRef]

57. Gottschalk, P.; Solli-Sæther, H. Critical success factors from IT outsourcing theories: An empirical study. Ind. Manag. Data Syst. 2005, 105, 685-702. [CrossRef]

58. Salmeron, J.L.; Herrero, I. An AHP-based methodology to rank critical success factors of executive information systems. Comput. Stand. Interfaces 2005, 28, 1-12. [CrossRef]

59. Tan, J.; Tyler, K.; Manica, A. Business-to-business adoption of eCommerce in China. Inf. Manag. 2007, 44, 332-351. [CrossRef]

60. Oliveira, T.; Martins, M.F. Firms patterns of e-business adoption: Evidence for the European Union-27. Electron. J. Inf. Syst. Eval. 2010, 13, 47-56.

61. Musawa, M.S.; Wahab, E. The adoption of electronic data interchange (EDI) technology by Nigerian SMEs: A conceptual framework. J. Bus. Manag. Econ. 2012, 3, 55-68.

62. Porter, M.E.; Millar, V.E. How Information Gives You Competitive Advantage. Technology. 1985. Available online: https://hbr.org/1985/07/how-information-gives-you-competitive-advantage (accessed on 6 August 2018).

63. Thong, J.Y. An integrated model of information systems adoption in small businesses. J. Manag. Inf. Syst. 1999, 15, 187-214. [CrossRef]

64. Zhu, K.; Xu, S.; Dedrick, J. Assessing drivers of e-business value: Results of a cross-country study. In Proceedings of the Twenty-Fourth International Conference on Information Systems, Seattle, WA, USA, 15-17 December 2003.

65. Armbrust, M.; Fox, A.; Griffith, R.; Joseph, A.D.; Katz, R.; Konwinski, A.; Stoica, I. A view of cloud computing. Commun. ACM 2010, 53, 50-58. [CrossRef]

66. Bhuasiri, W.; Xaymoungkhoun, O.; Zo, H.; Rho, J.J.; Ciganek, A.P. Critical success factors for e-learning in developing countries: A comparative analysis between ICT experts and faculty. Comput. Educ. 2012, 58, 843-855. [CrossRef]

67. Zahedi, F. The analytic hierarchy process-A survey of the method and its applications. Interfaces 1986, 16, 96-108. [CrossRef]

68. Yang, C.; Huang, J.B. A decision model for IS outsourcing. Intern. J. Inf. Manag. 2000, 20, 225-239. [CrossRef]

(C) 2018 by the authors. Licensee MDPI, Basel, Switzerland. This article is an open access article distributed under the terms and conditions of the Creative Commons Attribution (CC BY) license (http:/ / creativecommons.org/licenses/by/4.0/). 